\title{
RUMAH RAMAH BANJIR DI KAMPUNG PEJATEN TIMUR
}

\author{
Angie Abigail Setiawan ${ }^{1)}$ \\ 1)Program Studi S1 Arsitektur, Fakultas Teknik, Universitas Tarumanagara, gieabigail11@gmail.com
}

Masuk: 03-07-2021, revisi: 14-08-2021, diterima untuk diterbitkan: 23-10-2021

\begin{abstract}
Abstrak
Banjir di Jakarta terjadi hampir setiap tahunnya. Beberapa daerah bahkan mengalami banjir yang cukup parah dan mengkhawatirkan, sedangkan kondisi pengungsian juga masih belum memadai. Berdasarkan data yang diperoleh, titik banjir terbanyak di Jakarta berada di daerah Jakarta Selatan dengan 39 titik banjir dan salah satu daerah yang mengalami banjir terparah di Jakarta adalah Kampung Pejaten Timur. Kampung Pejaten Timur memiliki kontur tanah yang rendah. Akibatnya, banjir di Kampung Pejaten Timur dapat mencapai 2-3 meter. Banjir di Jakarta ini terjadi karena prinsip kotanya yang masih melawan air. Maka, prinsip bangunan yang cocok adalah bangunan yang tidak melawan banjir dan harus mampu hidup berdampingan dengan banjir, karena banjir Jakarta tidak dapat dihindari. Ada beberapa hal yang perlu diperhatikan ketika mendesain bangunan, antara lain; kebutuhan warga ketika banjir, aktivitas warga setempat baik ketika banjir maupun tidak banjir, serta bahan dan material yang digunakan dalam proyek untuk memungkinkan bangunan tahan terhadap banjir. Untuk itu metode yang digunakan dalam mendesain adalah dengan mengadaptasikan aktivitas warga ketika banjir ataupun tidak banjir kedalam bangunan. Dalam upaya membangun bangunan ramah banjir, proyek ini dibuat sebagai bangunan amfibi yang mampu beradaptasi, dengan dapat mengapung ketika banjir dan menjadi rumah panggung ketika tidak banjir. Dengan demikian, warga yang tinggal didalamnya tidak perlu lagi mengungsi dan rumah mereka juga aman ketika banjir datang.
\end{abstract}

\section{Kata kunci: Banjir; Hunian; Pejaten Timur}

\begin{abstract}
Floods in Jakarta occur almost every year. Some areas even experienced floods which were quite severe and worrying, while the conditions for the evacuation were still not sufficient. Based on the data obtained, the largest flood point in Jakarta is in the South Jakarta area with 39 flood points and one of the areas experiencing the worst flooding in Jakarta is Kampung Pejaten Timur. East Pejaten Village has a low land contour. As a result, flooding in East Pejaten Village can reach 2-3 meters. Floods in Jakarta occurred because the principle of the city is still against the flood. Thus, the principle of a suitable building is a building that resists flooding and must be able to live with floods, because Jakarta floods are unavoidable. Several things need to be considered when designing buildings, including the residents' needs during the flood, the residents' activities during and during the flood, and the materials used in the project to support flood-resistant buildings. For this reason, the method used in designing is to adapt the activities of residents when it is flooded or not flooded into the building. To build a flood-friendly building, this project was designed as an amphibious building that can adapt to flooding by floating, and become a stilt house when it is not flooded. Thus, the residents who live in it no longer need to evacuate and their homes are also safe when floods come.
\end{abstract}

\section{Keywords: Flood, Pejaten Timur, Residential}

\section{PENDAHULUAN}

\section{Latar Belakang}

Bencana alam merupakan suatu peristiwa alam yang berpengaruh besar terhadap kondisi ekosistem, termasuk manusia didalamnya. Bencana alam itu dapat berupa gempa bumi, banjir, tanah longsor, gunung meletus, dan lain sebagainya. 
Berdasarkan data yang diperoleh melalui berbagai berita, BNPB, dan BPBD, banjir merupakan salah satu bencana alam yang paling sering terjadi terutama di Jakarta. Banjir sendiri merupakan suatu kondisi di mana terjadi luapan air yang berlebih yang mengakibatkan terendamnya suatu wilayah. Banjir juga menjadi rutinitas yang terjadi dari tahun ketahun untuk beberapa tempat, dan bahkan meningkat terutama di berbagai kota besar. Berbagai macam solusi dari permasalahan banjir yang ditawarkan tidak dapat berjalan sesuai perkiraan dalam tataran operasional untuk menanggulangi serta mengurangi banjir, baik secara volume maupun persebarannya. Banyak faktor yang dapat menyebabkan terjadinya banjir, antara lain; penebangan hutan liar yang mengurangi resapan air, kebiasaan membuang sampah sembarangan sehingga menyumbat aliran air, kurang tertatanya pemukiman penduduk yang berada di daerah bantaran sungai, curah hujan yang tinggi, dan masih banyak lagi.

Banyak juga kerugian yang diakibatkan oleh banjir, misalnya kurangnya persediaan air bersih, munculnya berbagai macam penyakit, kerusakan pada bangunan, berbagai kerugian materi lainnya, dan bahkan bisa memakan korban jiwa.

Berdasarkan data mengenai bencana alam di Indonesia pada awal tahun 2021 ini, banjir menduduki peringkat pertama dengan angka tiga puluh tiga kejadian. Sedangkan menurut data BNPB dan BPBD tanggal 1 Januari 2020, lokasi banjir terparah di Jakarta ada di daerah Jakarta Selatan, dengan 39 titik banjir dan Jakarta Timur, dengan 13 titik banjir.

Latar belakang berisi landasan konseptual dan kaitannya dengan landasan kontekstual yang melatarbelakangi penelitian yang dilakukan. Latar belakang masalah menjelaskan secara ringkas beberapa teori, pengalaman, dan pengamatan pribadi yang terkait dengan pokok masalah yang diteliti. Pernyataan mengenai alasan-alasan mengapa masalah yang dikemukakan dalam penelitian/ perancangan merupakan hal yang penting, menarik, dan perlu untuk diteliti harus dijabarkan dengan jelas di latar belakang masalah.

\section{Rumusan Permasalahan}

Banjir yang merendam DKI Jakarta terjadi secara rutin setiap tahunnya, sedangkan masyarakat yang tinggal di area rawan banjir sering kali lebih memilih untuk tinggal di dalam rumah mereka hingga banjir meninggi dan menyulitkan proses evakuasi.

Berdasarkan sejarahnya, masalah banjir Jakarta tidak akan pernah selesai. Sedangkan, masalah yang diakibatkan oleh banjir bukan hanya kerugain materi atau kekurangan air bersih saja. Masalah kurangnya tempat pengungsian yang layak juga menjadi masalah yang serius, terutama ditengah pandemi seperti sekarang ini.

\section{Banjir hingga 3 Meter, Warga Pejaten Timur Ngemper di Rumah Tetangga}

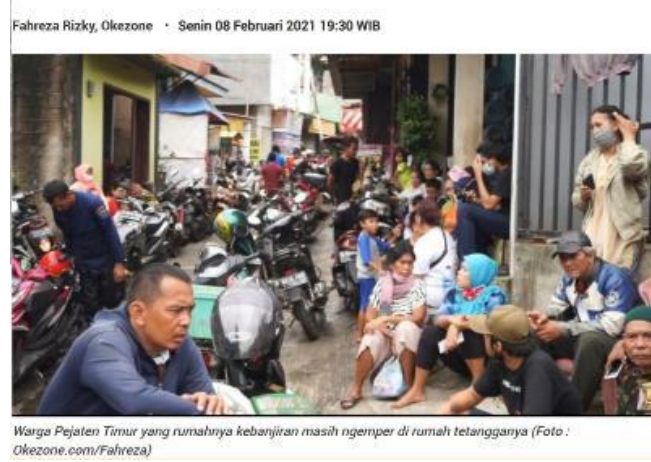

Gambar 1. Kondisi Pengungsian Ketika Banjir Sumber: Megapolitan.okezone.com 
Jika dilihat berdasarkan data korban banjir yang mengungsi, pada tahun 2020 jumlah pengungsi melonjak jauh hingga lebih dari 50.000 jiwa. Padahal, jumlah tempat pengungsian saat ini belum memadai.

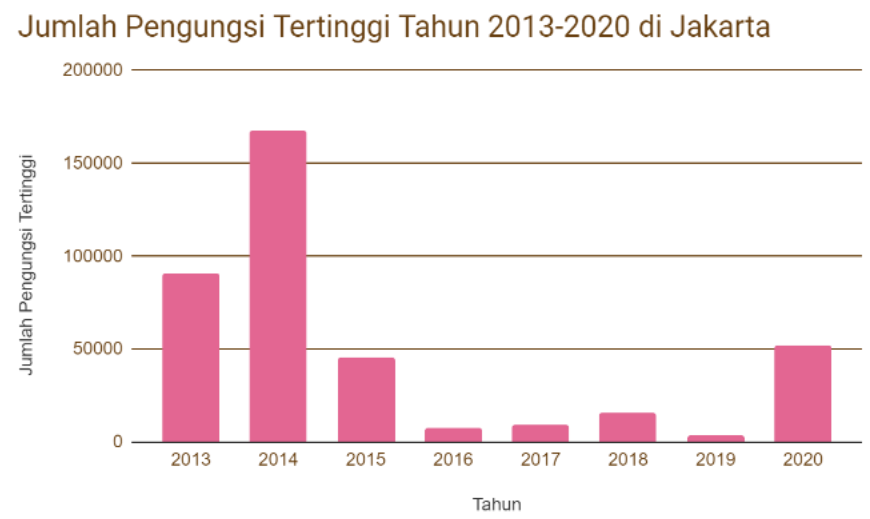

Gambar 2. Grafik Jumlah Pengungsi Tertinggi Tahun 2013-2020 di Jakarta Sumber: BNPB dan BPBD

\section{Tujuan}

Kondisi kota Jakarta rutin terdampak banjir setiap tahunnya. Oleh karena itu, Jakarta membutuhkan prinsip tata kota yang ramah air. Konsep kota ramah air ini dapat diwujudkan dengan cukupnya ruang terbuka hijau yang menjadi sarana resapan air. Selain itu, kebiasaan warga yang tetap menetap didalam rumah mereka hingga banjir menjadi parah, membutuhkan response bangunan yang ramah banjir sehingga orang yang tinggal didalamnya tidak perlu mengungsi dan tetap aman didalamnya ketika banjir tiba. Maka, studi perancangan tersebut ingin memberi solusi penyediaan wadah dan program arsitektural yang dapat menunjang kebutuhan warga ketika banjir. Pertama, adanya hunian dan rumah ungsi yang dapat mengapung ketika banjir dan tetap dapat dihuni baik saat banjir ataupun tidak banjir. Kedua, menyediakan program daur ulang sampah organik dan penyediaan air bersih dari air banjir.

\section{KAJIAN LITERATUR}

\section{Bencana Banjir di Jakarta}

Berdasarkan data yang diperoleh melalui berbagai berita, BNPB, dan BPBD, banjir merupakan salah satu bencana alam yang paling sering terjadi terutama di Jakarta. Banjir sendiri merupakan suatu peristiwa atau keadaan dimana suatu daerah terendam karena volume air yang meningkat. Sedangkan banjir bandang adalah banjir yang datang secara tiba-tiba dengan debit air yang besar yang disebabkan terbendungnya aliran sungai pada alur sungai.

Ada beberapa faktor penyebab banjir di DKI Jakarta, antara lain; hujan yang jatuh di sekitar Jabodetabek yang bermuara di Jakarta, hujan yang jatuh di Jakerta sendiri, serta ada pasang laut. Bahkan berdasarkan sejarahnya, banjir Jakarta sudah dimulai sejak Pemerintahan Hindia Belanda. Awalnya pada tahun 1619, Jan Pieterszoon Coen meminta Simon Stevin merancang sebuah kota di muara Sungai Ciliwung yang sering kebanjiran sebagaimana Kota Amsterdam di Belanda. Selain itu, Kota Jakarta juga dialiri 13 sungai yang menjadikan Jakarta memiliki dataran banjir yang banyak tersebar. Maka dari itu, potensi terjadinya banjir di DKI Jakarta setiap tahunnya sangat tinggi.

Selain curah hujan yang tinggi baik di Jakarta maupun daerah sekitarnya, penyebab banjir di Jakarta adalah karena normalisasi sungai Ciliwung yang belum tuntas. Faktor yang menghambat normalisasi ini salah satunya adalah karena sempitnya lahan akibat banyaknya rumah warga di palung sungai. Hal ini juga menyebabkan Jakarta kekurangan ruang terbuka hijau sebagai 
resapan air. Maka dari itu, dapat disimpulkan bahwa sistem tata kota Jakarta masih melawan banjir yang mengakibatkan potensi banjir Jakarta juga semakin besar.

\section{Konsep Tata Kota Ramah Air}

Jika kita perhatikan, masalah banjir yang terjadi di Jakarta tidak pernah ada habisnya. Masalah banjir ini sudah terjadi sejak masa kolonial dan masih tetap terjadi hingga sekarang ini.

Menurut Yu Sing, arsitek lulusan Institut Teknologi Bandung (ITB), Jakarta merupakan kota rawa dan hidup dengan air. Maka, untuk mengatasi permasalahan banjir, tata kota Jakarta harus ramah air. Konsep tata kota ramah air bisa terlihat dengan adanya ruang terbuka hijau yang terjaga, sebagai sarana resapan air. Jika kota tak ramah air dan resapan air semakin berkurang, maka terjadilah banjir.

Secara alami, Jakarta yang merupakan kota rawa dapat terlihat dengan penamaan banyak daerah Jakarta dengan nama rawa, misalnya; Rawa Belong, Rawa Bebek, Rawa Bening, dan sebagainya. Maka, jika daerah yang awalnya merupakan rawa diubah menjadi perumahan atau bangunan lain, air yang ada di rawa tersebut akan berpindah tempat ke area yang lebih rendah dan membuat banjir.

Disamping itu, kota ramah air juga sebaiknya tidak melakukan normalisasi sungai dengan cara betonisasi. Betonisasi ini akan membuat sungai berubah menjadi saluran air karena sungai alami memiliki vegetasi, batu-batuan, ikan, dan berbagai ekosistem di dalamnya yang akan menjadi rusak dan mati. Fungsi sungai alami selain menjadi ruang hidup, adalah menjadi tempat retensi dan penyaring polutan melalui akar-akar pohon yang ada. Jadi, jika dilakukan betonisasi, tidak akan ada lagi penyaring polutan dan ekosistem sungai menjadi hilang.

Akan tetapi, masalah banjir di Jakarta bukan hanya permasalahan masyarakat yang tinggal di bantaran sungai, namun seluruh pembangunan di Jakarta yang harus mampu menyerap limpahan air hujan. Masalah banjir ini tidak akan selesai jika hanya dari sungai, tetapi dengan tata kota Jakarta yang tidak lagi melawan air dan mampu hidup bersama air. Arsitek Yu Sing: Banjir karena Jakarta Melawan Air (2018, Maret).

\section{Panduan Struktur}

Untuk mendesain bangunan amfibi yang kokoh dan tahan terhadap banjir, tentunya diperlukan juga struktur yang baik dan sesuai. Berdasarkan teori dari Graham Marden dalam Common Construction Methodes and Log Float Specs, digambarkan metode konstruksi konvensional untuk bangunan yang mengapung. Graham menyatakan bahwa tinggi bangunan tidak boleh lebih dari $75 \%$ dari panjang bangunan.

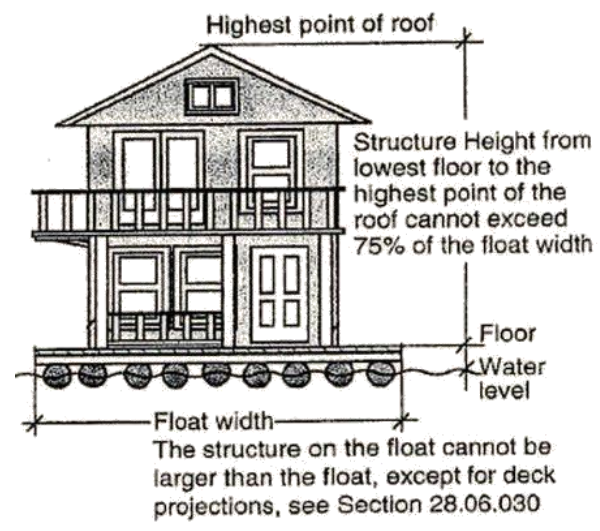

Gambar 3. Metode Konstruksi Konvensional untuk Struktur Apung Sumber: Oregon-floating-homes.com 
Selain itu, di ada juga prinsip mengapung yang digunakan pada bangunan seperti prinsip mengapung pada kapal. Melalui perhitungan rumus pada hukum Archimedes dan buoyancy dimana kapal dapat mengapung jika $\mathrm{F}$ (gaya buoyancy) > daripada W (berat kapal). Maka, jika berat bangunan lebih ringan daripada daya pengapungnya, bangunan juga dapat mengapung seperti kapal.

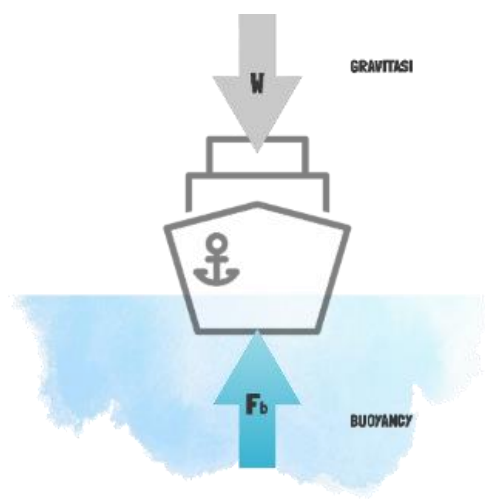

Gambar 4. Prinsip Kapal Mengapung Sumber: Penulis, 2021

\section{METODE}

Ada beberapa metode yang digunakan dalam perancangan proyek ini:

a. Studi Literatur

Studi literatur yang diambil dari data BPBD dan BNPB untuk mengetahui jenis bencana yang paling sering terjadi serta lokasi banjir terparah di Jakarta. Selain itu, ada juga penerapan konsep yang diutarakan Yu Sing mengenai Tata Kota Ramah Air serta parameter beyond ecology dari kuliah 'Dromos Oikos' yang kemudian menjadi landasan dalam perancangan rumah amfibi ini.

b. Studi Preseden

Ada pula beberapa studi preseden yang menjadi referensi dalam mendesain, yaitu; Amphibious Homes for The Vulnerable oleh Waterloo Architecture, The LifE Project oleh Baca Architects, Lift House oleh Prosun Architects, Floating House at Benowo oleh Yu Sing dan Yopie, dan Kampung (Susun) Pulo oleh Studio Akanoma.

c. Survei

Survei lapangan dan wawancara warga dilakukan untuk mengetahui aktivitas apa saja yang biasa dilakukan, baik ketika banjir maupun tidak banjir. Serta untuk mengetahui apa saja kebutuhan warga ketika banjir tiba.

d. Perhitungan Struktur

Desain bangunan tidak hanya memikirkan fungsinya saja, namun juga ketahanan dan adaptasi bangunan ketika banjir. Ketahanan dan adaptasi ini didukung oleh perhitungan struktur yang sesuai, yang memungkinkan bangunan untuk dapat mengapung ketika banjir. Dalam perhitungan ini, digunakan teori dari Graham Marden dalam Common Construction Methodes and Log Float Specs serta rumus buoyancy dan Hukum Archimedes seperti yang digunakan dalam perhitungan kapal yang mengapung.

e. Everydayness

Adapun proses desain yang digunakan dalam perancangan, mulai dari analisis tapak dan pengaplikasian terhadap desain serta kebutuhan warga pada tapak.

\section{DISKUSI DAN HASIL}

\section{Pemilihan Lokasi}

Lokasi yang dipilih menjadi tapak perancangan terletak di kawasan Pejaten Timur. Pejaten Timur dipilih karena lokasi ini sering mengalami banjir yang tergolong parah setiap tahunnya. Banjir 
yang terjadi di Pejaten Timur ini biasanya mencapai 2-3 meter, bahkan pernah mencapai 6 meter pada Januari 2014 silam. Tapak terpilih merupakan zona permukiman warga dengan luas kawasan $11.684 \mathrm{~m}^{2}$ dan luas tapaknya $5.864 \mathrm{~m}^{2}$. Area ini dihuni oleh 62 keluarga dengan anggota 4-5 orang, selain itu ada juga fasilitas sekolah SD yang terletak pada tapak.

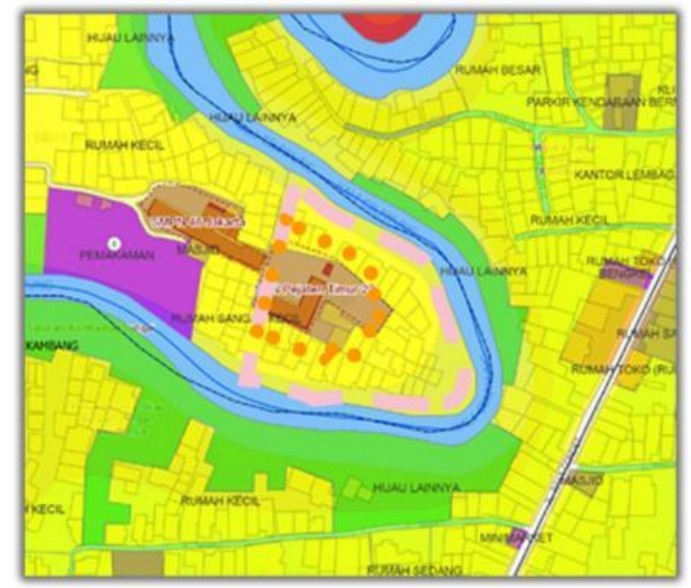

Gambar 5. Peta Zonasi Eksisting Sumber: Jakarta Satu

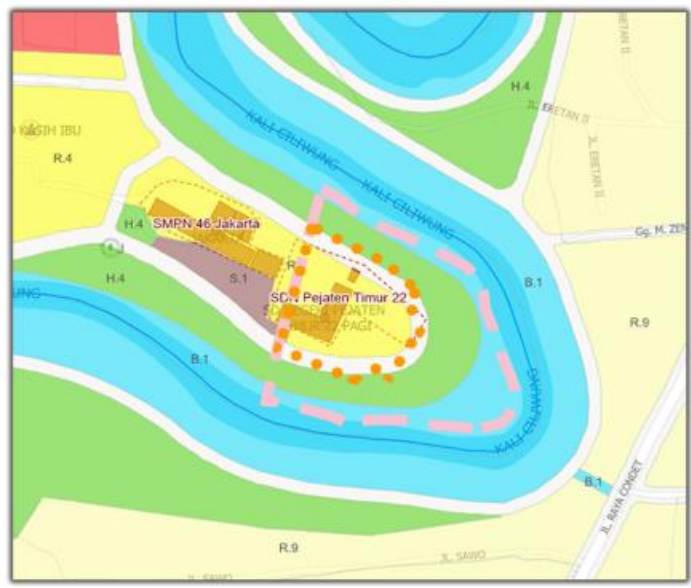

Gambar 6. Peta Zonasi RDTR Sumber: Jakarta Satu

Jika kita bandingkan peta zonasi eksisting (Gambar 5) dengan peta zonasi RDTR (Gambar 6), maka dapat disimpulkan bahwa keadaan tapak eksisting sangat jauh berbeda dengan zonasi yang seharusnya. Area yang seharusnya menjadi area hijau saat ini masih diperuntukkan warga sebagai tempat tinggal.

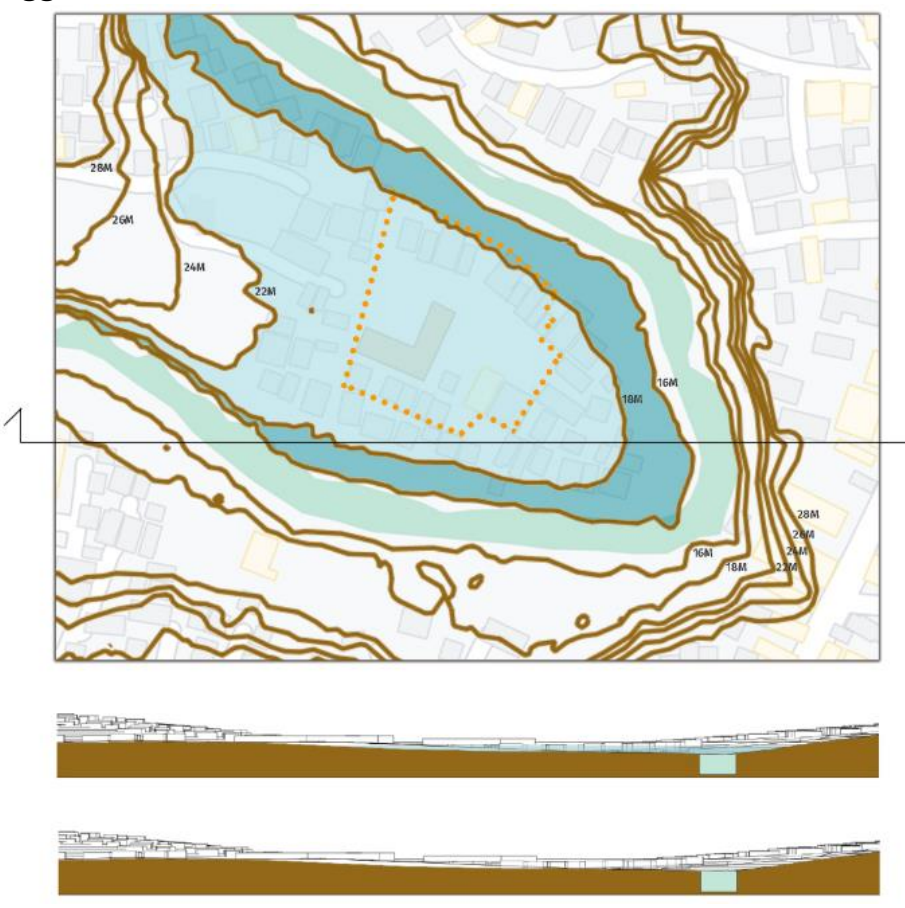

Gambar 7. Peta dan Kontur Tapak

Sumber: Penulis, 2021

Tapak memiliki kontur tanah yang rendah, sehingga ketika musim penghujan tiba, kawasan tersebut cenderung mengalami banjir yang cukup parah dibandingkan kawasan sekitarnya. Letaknya yang berbatasan dengan sungai Ciliwung, membentuk lengkungan yang membendung tapak ketika banjir. 
Jika kita perhatikan dari potongan kontur (Gambar 7), kontur ke arah Condet, Jakarta Timur jauh lebih curam daripada yang ke arah Jakarta Selatan. Maka, area tapak yang berada di Jakarta Selatan mengalami banjir yang lebih parah. Selain itu, daerah Condet, Jakarta Timur, yang letaknya lebih tinggi dari tapak, mengalami pengikisan tanah ketika banjir, karena tanah itu terbawa arus sampai ke tapak. Akibatnya, tanah pada tapak mengalami kenaikan setelah banjir.

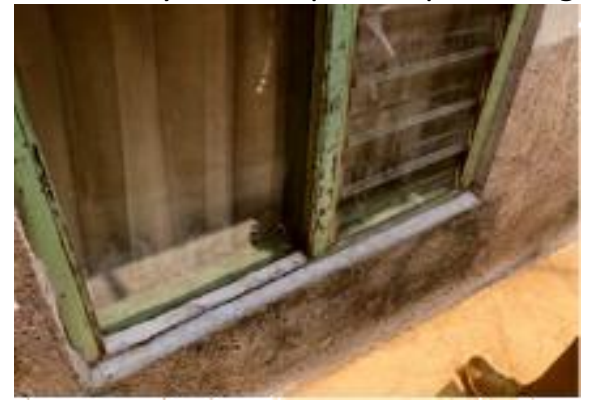

Gambar 8. Jendela Rumah Warga Sumber: Penulis, 2021

Bukti kenaikan tanah pada tapak dapat terlihat dari posisi jendela rumah warga yang sangat rendah dibangingkan posisi jendela pada umumnya.
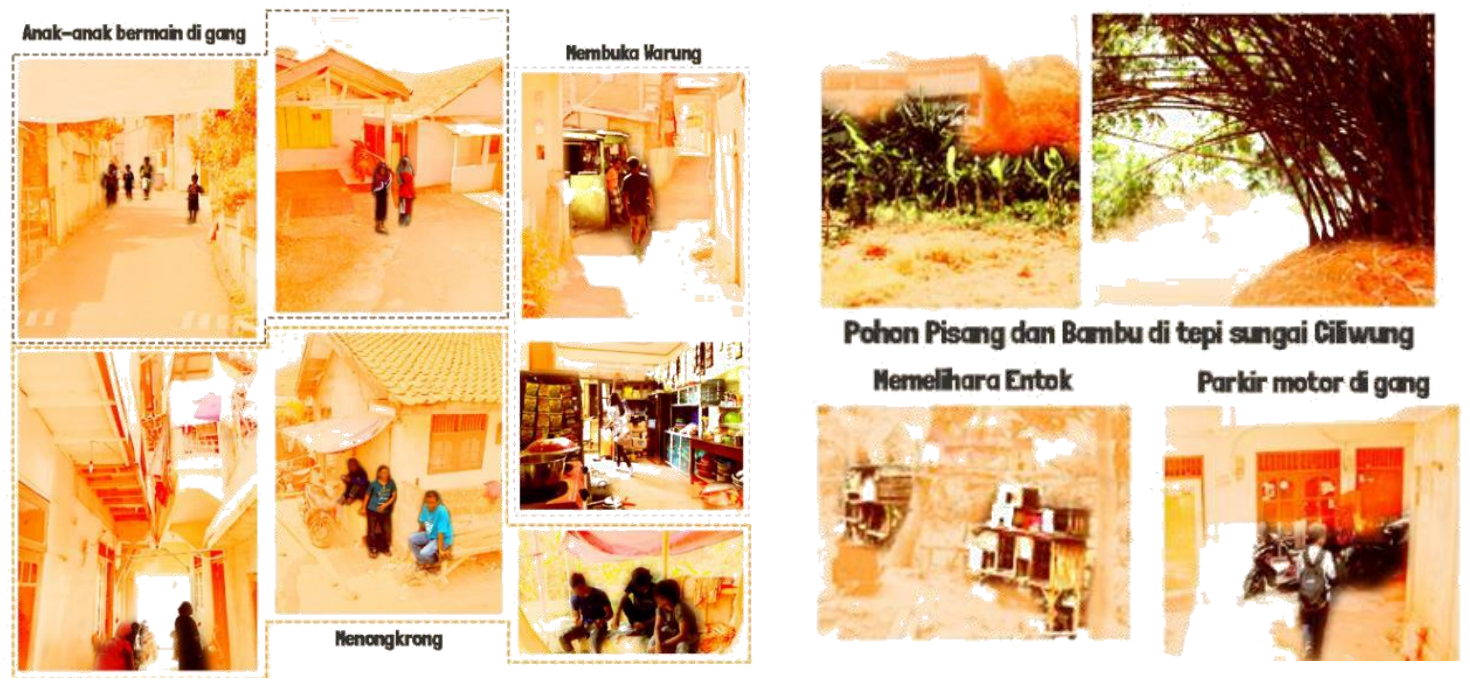

Gambar 9. Aktivitas Warga pada Tapak Sumber: Penulis, 2021

Aktivitas yang biasa dilakukan warga sehari-hari antara lain; membuka warung, menongkrong/ngobrol, anak-anak yang bermain di gang, serta memelihara entok. Selain itu, dapat dilihat juga kebiasaan warga yang memarkir motor nya di gang depan rumah mereka. Dapat diperhatikan juga kebiasaan unik beberapa warga yang membuka warung di lantai 2 rumah mereka. Hal ini terjadi sebagai bentuk adaptasi warga terhadap banjir untuk mengamankan dagangan mereka supaya tidak habis terkena banjir yang seringkali datang. Pada area tapak dapat ditemukan juga pohon pisang dan pohon bambu yang berada di tepi sungai. Pohon bambu ini dapat berfungsi sebagai pencegah banjir supaya tidak semakin parah. 


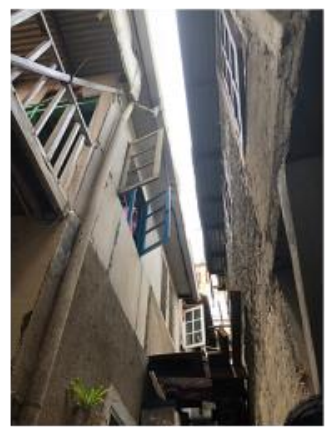

Gambar 10. Jendela Rumah Warga

Sumber: Penulis, 2021

Selain itu, dapat dilihat juga bentuk adaptasi rumah warga yang dibuat berhadapan pada bagian jendela lantai 2 mereka (Gambar 10). Menurut warga, hal ini akan memudahkan mereka saat proses evakuasi ketika banjir, dimana warga akan menggunakan tangga rotan sebagai jembatan dari jendela ke jendela. Hal ini terjadi karena kebiasaan warga yang lebih memilih untuk tetap tinggal di rumah ketika banjir sehingga mereka harus melakukan evakuasi darurat menggunakan getek atau pindah melalui jendela rumah yang satu ke rumah yang lain.

\section{Program}

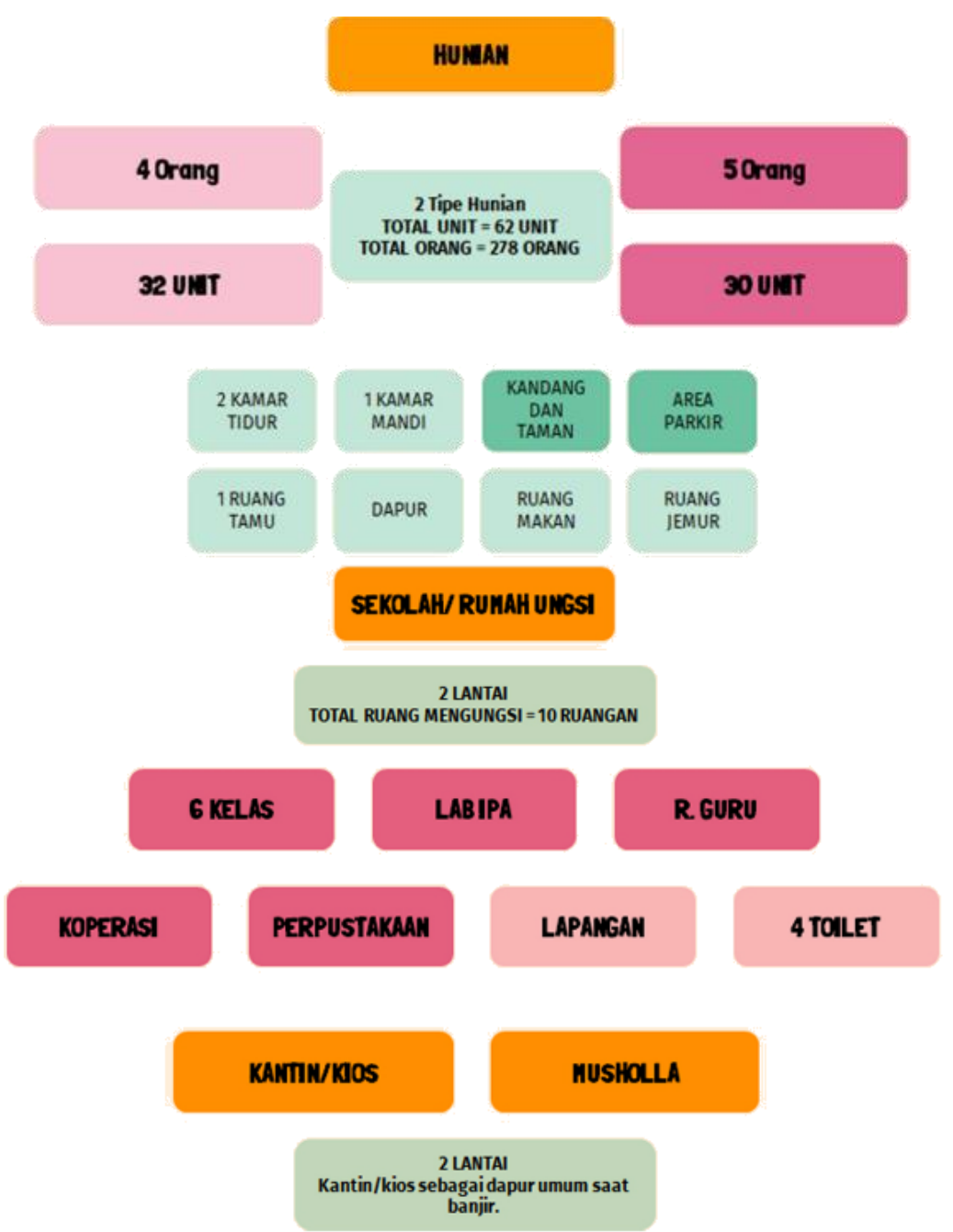

Gambar 11. Diagram Program

Sumber: Penulis, 2021 
Program disusun sesuai dengan kebutuhan warga, maka tipe rumah warga dibuat untuk 4-5 orang dengan total 62 unit, sesuai dengan kondisi rumah eksisting. Selain itu, ada juga fasilitas sekolah seperti sekolah yang ada pada tapak, yang juga dapat difungsikan sebagai rumah ungsi bagi warga yang tinggal di sekitar tapak ketika terjadi banjir.

\begin{tabular}{|c|c|c|c|c|c|c|}
\hline RUANGAN: & JỤMLÄH & BESARAN & LUAS: & TOTAL LUAAS & JUMLAH DI LANTAZI 1 & LUASLANTAI \\
\hline UNIT: 5:ORANG & 30. & $5,5 \times 9$ & 49.5 & 1485 & 8 & 396 \\
\hline UNIT 4 ORANG & 32 & $5 \times 9$ & 45 & $1440^{\circ}$ & 10 & 450 \\
\hline KANDANG ENTOK & 4 & $2 \times 2$ & 4 & 16 & 4 & 16 \\
\hline Kios & 1 & $8 \times 16$. & 128 & 128 & 1 & 128 \\
\hline MUSHOLLA & 1 & $8 \times 10$ & 128 & $128:$ & 0 & 0 \\
\hline KELAS & 6 & $7 \times 10^{\circ}$ & 70 & 420 & 4 & 280 \\
\hline PERPUSTAKAAN: & 1 & $7 \times 10$ & $70:$ & $70 \tilde{0}$ & 0 & 0 \\
\hline LAB IPA & 1 & $7 \times 10$. & 70. & 70 & 0 & 0 \\
\hline R. GURU: & 1 & $5 \times 11$ & 55 & 55 & 1 & $55:$ \\
\hline R KOPERASI & 1 & $5 \times 11$ & 55 & 55 & 1 & 55. \\
\hline TOILET SEKOLLAH & 4 & $3.5 \times 3$ & 10,5 & 42 & 2. & 21 \\
\hline LAPANGAN & 1 & $13 \times 22$ & 286 & $286:$ & - & - \\
\hline PARKIR MÒTOR & 72 & $0.75 \times 2$ & 1.5 & 108 & - & $\because$ \\
\hline SIRKULASI $30 \%$ & & & & 12909 & & 420.3 \\
\hline TOTAL LUAS & & & & 5593.9 & & 1821.3 \\
\hline
\end{tabular}

Gambar 12. Tabel Program Ruang Sumber: Penulis, 2021

$\begin{array}{ll}\text { Luas Kawasan } & : 11.684 \mathrm{~m}^{2} \\ \text { Luas Tapak } & : 5.864 \mathrm{~m}^{2} \\ \text { Peruntukkan Lahan } & : \text { Perumahan } \\ \text { KDB }: 60 \% & =3.518,4 \mathrm{~m}^{2} \\ \mathrm{KLB} \quad: 1,2 & =7.036,8 \mathrm{~m}^{2} \\ \mathrm{KDH} \quad: 20 \% & =1.172,8 \mathrm{~m}^{2}\end{array}$

\section{Strategi Desain}

Dalam menghadapi kondisi tapak yang sering mengalami banjir, bangunan harus mampu beradaptasi terhadap banjir. Maka, strategi desainnya adalah dengan menggunakan drum pengapung dan kolom carbon fibre yang ringan serta tahan terhadap air yang memungkinkan bangunan untuk mengapung namun tidak berpindah ketika banjir (Gambar 13).

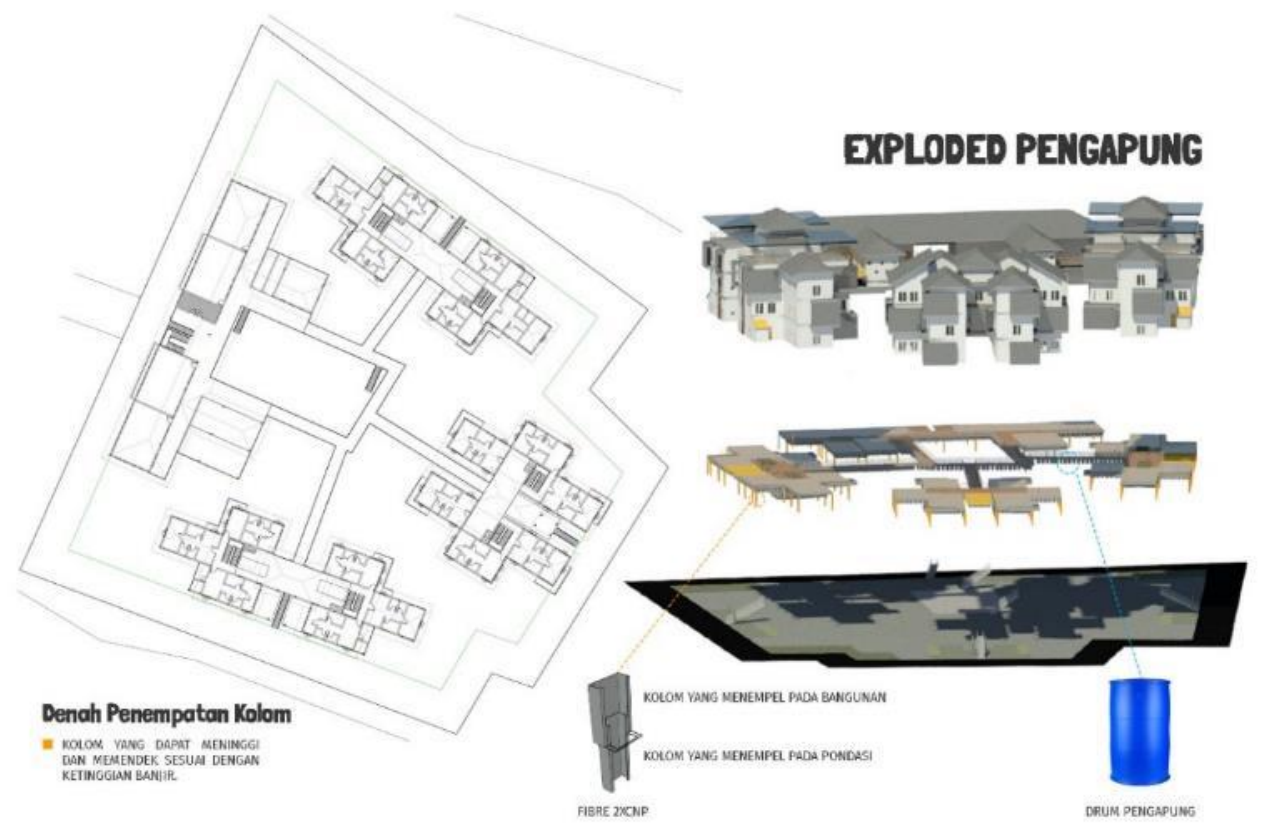

Gambar 13. Denah Penempatan Kolom dan Exploded Pengapung Sumber: Penulis, 2021 


\section{Perhitungan Struktur}

Desain bangunan yang mengapung mungkin terjadi dengan adanya pembuktian dari perhitungan yang dilakukan dengan rumus buoyancy dan hukum Archimedes. Pertama-tama, perlu dihitung berat setiap massa bangunan. Kemudian dihitung juga gaya apung setiap massa nya untuk membuktikan apakah bangunan tersebut dapat mengapung atau tidak.
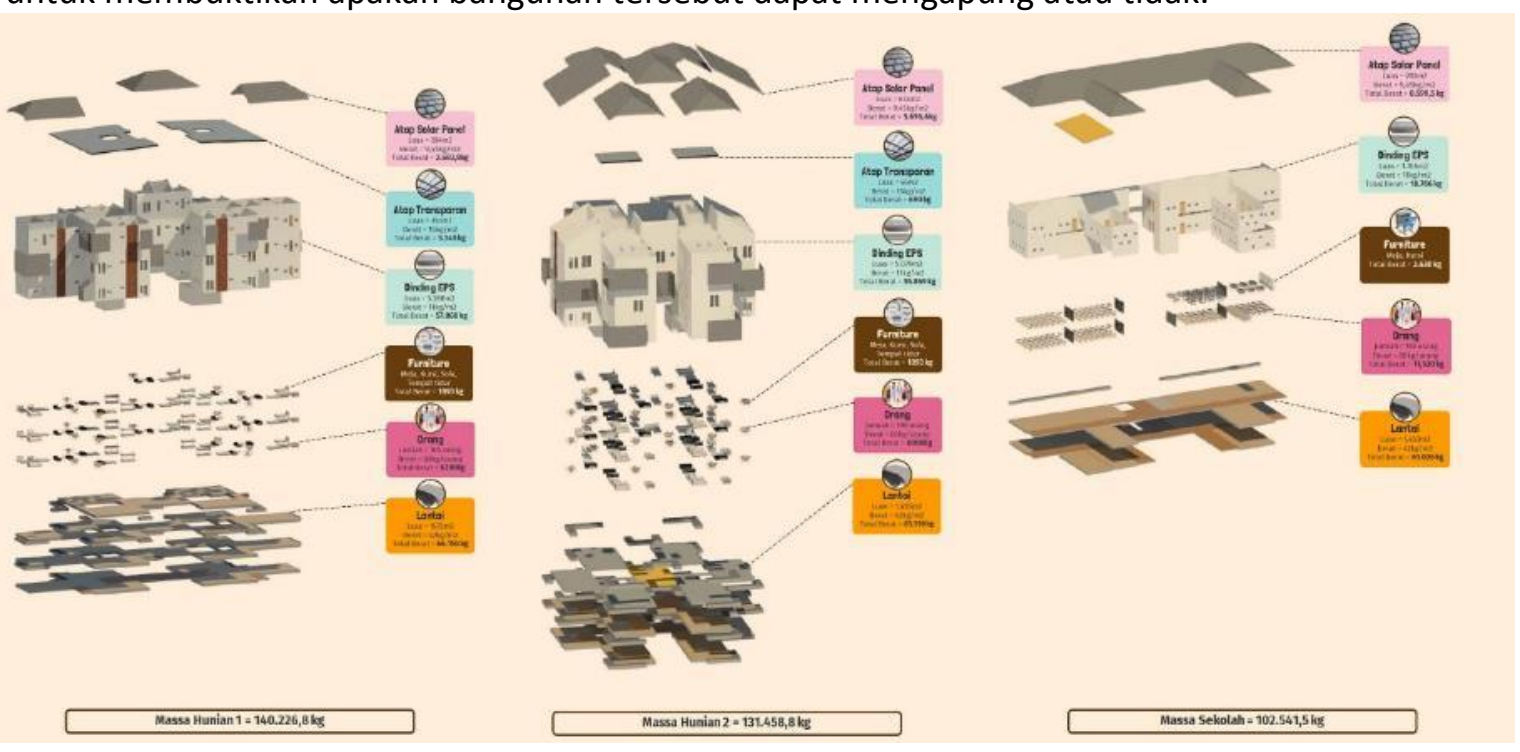

Gambar 14. Exploded Penyusun Bangunan

Sumber: Penulis, 2021

a. Pembuktian Hunian 1

Tabel 1. Perhitungan Massa Hunian 1

\begin{tabular}{llll}
\hline Jenis & Luas $/$ Jumlah & Berat & Total Berat \\
\hline Dinding EPS & $5.260 \mathrm{~m}^{2}$ & $11 \mathrm{~kg} / \mathrm{m}^{2}$ & $57.860 \mathrm{~kg}$ \\
\hline Atap Transparan & $356 \mathrm{~m}^{2}$ & $15 \mathrm{~kg} / \mathrm{m}^{2}$ & $5.340 \mathrm{~kg}$ \\
\hline Atap Solar Panel & $284 \mathrm{~m}^{2}$ & $9,45 \mathrm{~kg} / \mathrm{m}^{2}$ & $2.683,8 \mathrm{~kg}$ \\
\hline Lantai & $1.575 \mathrm{~m}^{2}$ & $42 \mathrm{~kg} / \mathrm{m}^{2}$ & $66.150 \mathrm{~kg}$ \\
\hline Furniture & & & $1.893 \mathrm{~kg}$ \\
\hline Orang & 105 orang & $60 \mathrm{~kg} /$ orang & $6.300 \mathrm{~kg}$ \\
\hline Massa Hunian 1 & & & $140.226,8 \mathrm{~kg}$ \\
\hline
\end{tabular}

Sumber: Dokumen Pribadi

Perhitungan Berat (W) dan Gaya Apung (Fb) Hunian 1

ht $=$ tinggi drum $=1 \mathrm{~m}$

$A=426,5 \mathrm{~m}^{2}$

$\mathrm{Vt}=\mathrm{Cb} . \mathrm{At} \cdot \mathrm{ht}$

$\mathrm{Vt}=0,8.426,5.1$

$\mathrm{Vt}=341,2 \mathrm{~m}^{3}$

$\mathrm{Fb}=\rho . g \cdot \mathrm{Vt}$

$\mathrm{Fb}=1000 \cdot 10 \cdot 341,2$

$\mathrm{Fb}=3.412 .000 \mathrm{~N}$

Untuk dapat mengapung $\mathrm{Fb}>\mathrm{W}$

Maka, jika $W=140.226,8.10$

$\mathrm{W}=1.402 .268 \mathrm{~N}$

Dan $\mathrm{Fb}=3.412 .000 \mathrm{~N}$ 
Hunian 1 terbukti mengapung.

Tabel 2. Perhitungan Massa Hunian 2

\begin{tabular}{llll}
\hline Jenis & Luas / Jumlah & Berat & Total Berat \\
\hline Dinding EPS & $5.079 \mathrm{~m}^{2}$ & $11 \mathrm{~kg} / \mathrm{m}^{2}$ & $55.869 \mathrm{~kg}$ \\
\hline Atap Transparan & $46 \mathrm{~m}^{2}$ & $15 \mathrm{~kg} / \mathrm{m}^{2}$ & $690 \mathrm{~kg}$ \\
\hline Atap Solar Panel & $624 \mathrm{~m}^{2}$ & $9,45 \mathrm{~kg} / \mathrm{m}^{2}$ & $5.896,8 \mathrm{~kg}$ \\
\hline Lantai & $1.455 \mathrm{~m}^{2}$ & $42 \mathrm{~kg} / \mathrm{m}^{2}$ & $61.110 \mathrm{~kg}$ \\
\hline Furniture & & & $1.893 \mathrm{~kg}$ \\
\hline Orang & 100 orang & $60 \mathrm{~kg} /$ orang & $6.000 \mathrm{~kg}$ \\
\hline Massa Hunian 2 & & & $131.458,8 \mathrm{~kg}$ \\
\hline
\end{tabular}

Sumber: Penulis, 2021

Perhitungan Berat (W) dan Gaya Apung (Fb) Hunian 2

ht $=$ tinggi drum $=1 \mathrm{~m}$

$\mathrm{A}=445,28 \mathrm{~m}^{2}$

$\mathrm{Vt}=\mathrm{Cb}$. At.ht

$\mathrm{Vt}=0,8.445,28.1$

$\mathrm{Vt}=356,224 \mathrm{~m}^{3}$

$\mathrm{Fb}=\rho . g \cdot \mathrm{Vt}$

$\mathrm{Fb}=1000 \cdot 10 \cdot 356,224$

$\mathrm{Fb}=3.562 .240 \mathrm{~N}$

Untuk dapat mengapung $\mathrm{Fb}>\mathrm{W}$

Maka, jika $W=131.458,8.10$

$W=1.314 .588 \mathrm{~N}$

Dan $\mathrm{Fb}=3.562 .240 \mathrm{~N}$

Hunian 2 terbukti mengapung.

b. Pembuktian Sekolah

Tabel 3. Perhitungan Massa Sekolah

\begin{tabular}{llll}
\hline Jenis & Luas $/$ Jumlah & Berat & Total Berat \\
\hline Dinding EPS & $1.706 \mathrm{~m}^{2}$ & $11 \mathrm{~kg} / \mathrm{m}^{2}$ & $58.766 \mathrm{~kg}$ \\
\hline Atap Solar Panel & $910 \mathrm{~m}^{2}$ & $9,45 \mathrm{~kg} / \mathrm{m}^{2}$ & $8.599,5 \mathrm{~kg}$ \\
\hline Lantai & $1.453 \mathrm{~m}^{2}$ & $42 \mathrm{~kg} / \mathrm{m}^{2}$ & $61.026 \mathrm{~kg}$ \\
\hline Furniture & & & $2.630 \mathrm{~kg}$ \\
\hline Orang & $192 \mathrm{orang}$ & $60 \mathrm{~kg} /$ orang & $11.520 \mathrm{~kg}$ \\
\hline Massa Sekolah & & & $102.541,5 \mathrm{~kg}$ \\
\hline Sumber: Penulis, 2021 & & &
\end{tabular}

Sumber: Penulis, 2021

Perhitungan Berat (W) dan Gaya Apung (Fb) Sekolah

ht $=$ tinggi drum $=1 \mathrm{~m}$

$\mathrm{A}=764 \mathrm{~m}^{2}$

$\mathrm{Vt}=\mathrm{Cb} \cdot \mathrm{At} \cdot \mathrm{ht}$

$\mathrm{Vt}=0,8.764 .1$

$\mathrm{Vt}=611,2 \mathrm{~m}^{3}$

$\mathrm{Fb}=\rho . g . \mathrm{Vt}$

$\mathrm{Fb}=1000.10 \cdot 611,2$

$\mathrm{Fb}=6.112 .000 \mathrm{~N}$ 
Untuk dapat mengapung $\mathrm{Fb}>\mathrm{W}$

Maka, jika $W=102.541,5.10$

$\mathrm{W}=1.025 .415 \mathrm{~N}$

Dan $\mathrm{Fb}=6.112 .000 \mathrm{~N}$

Sekolah terbukti mengapung.

\section{Hasil Desain}

Bangunan didesain dengan menggunakan material yang ringan dan tahan air seperti dinding EPS dan kolom carbon fibre. Ada pula adaptasi aktivitas yang diwadahi pada tapak yaitu; berdagang di area kios/kantin, nongkrong, sekolah, area bermain anak, memelihara entok, tempat tinggal warga, dan tempat pengungsian bagi warga sekitar tapak. Selain itu, ada juga aktivitas dan program yang mendukung kebutuhan warga terutama ketika banjir, seperti; berkebun sebagai salah satu sumber pangan, budidaya maggot BSF untuk pengolahan sampah organik serta menghasilkan pupuk kasgot dan pakan entok, serta memancing ketika banjir.
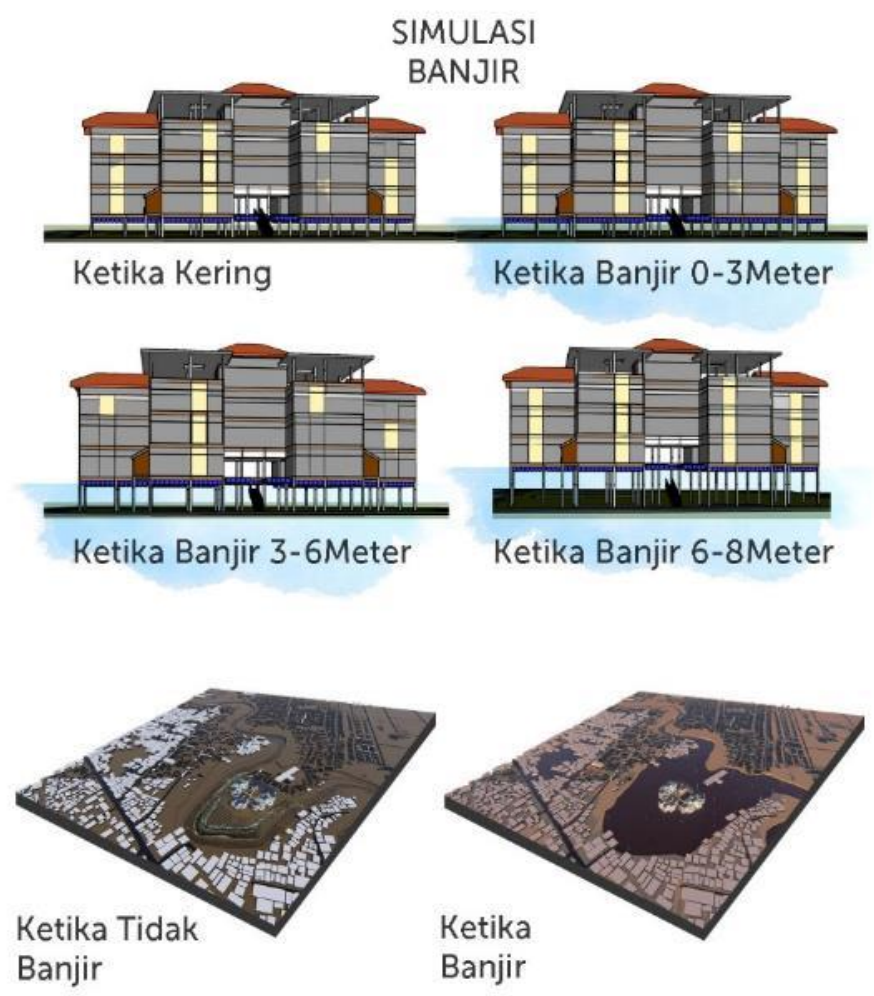

Gambar 18. Simulasi Banjir

Sumber: Penulis, 2021

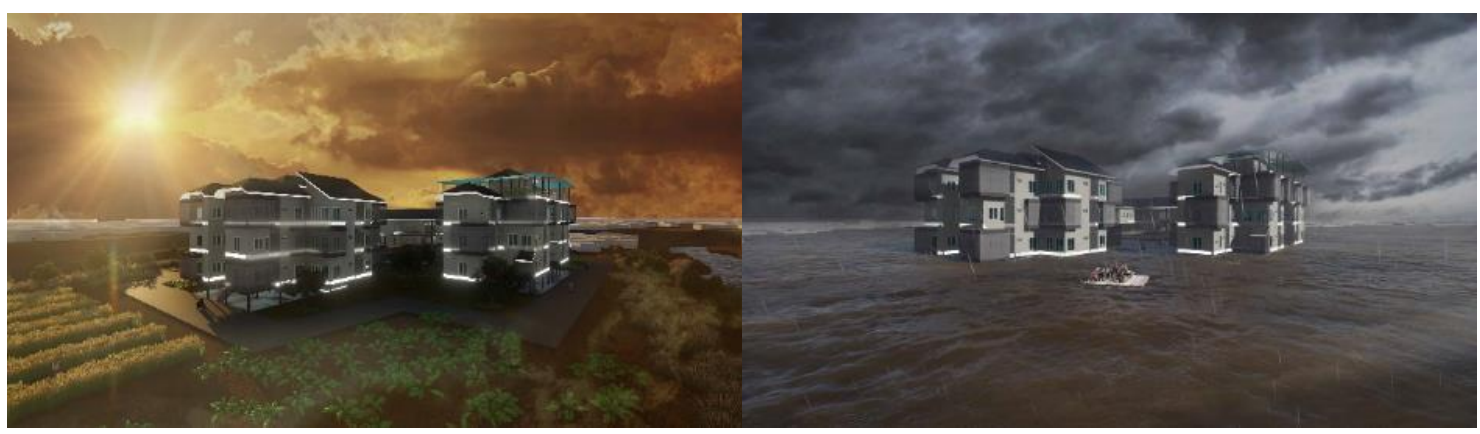

Gambar 19. Perspektif Ketika Tidak Banjir dan Ketika Banjir Sumber: Penulis, 2021 


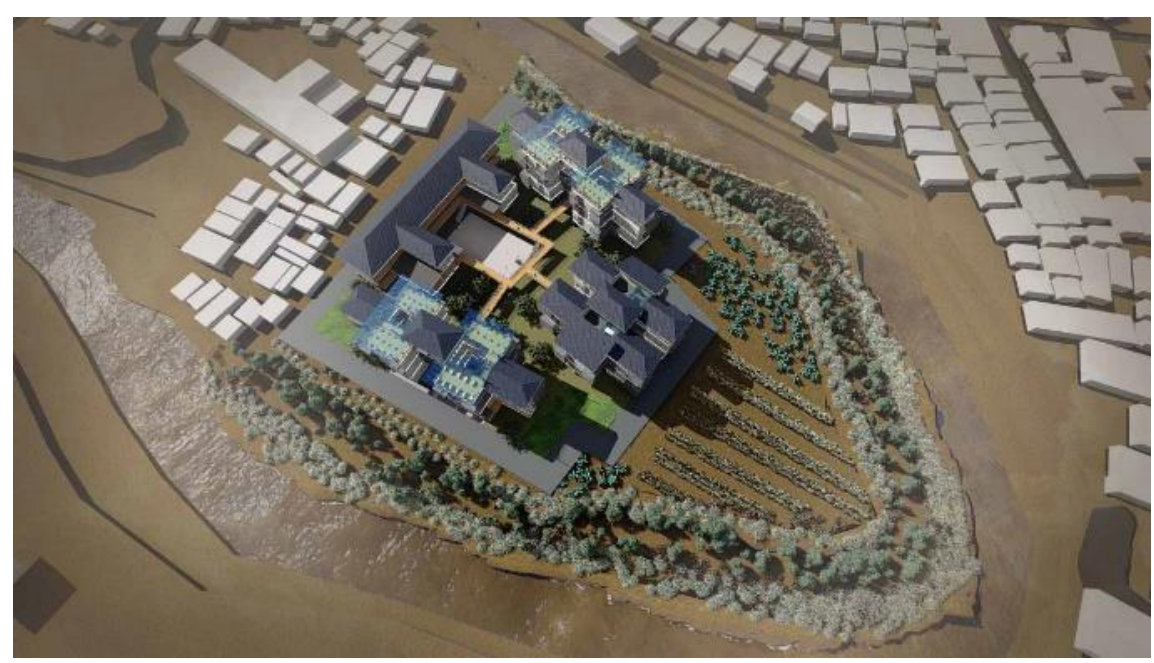

Gambar 20. Perspektif Mata Burung Sumber: Penulis, 2021

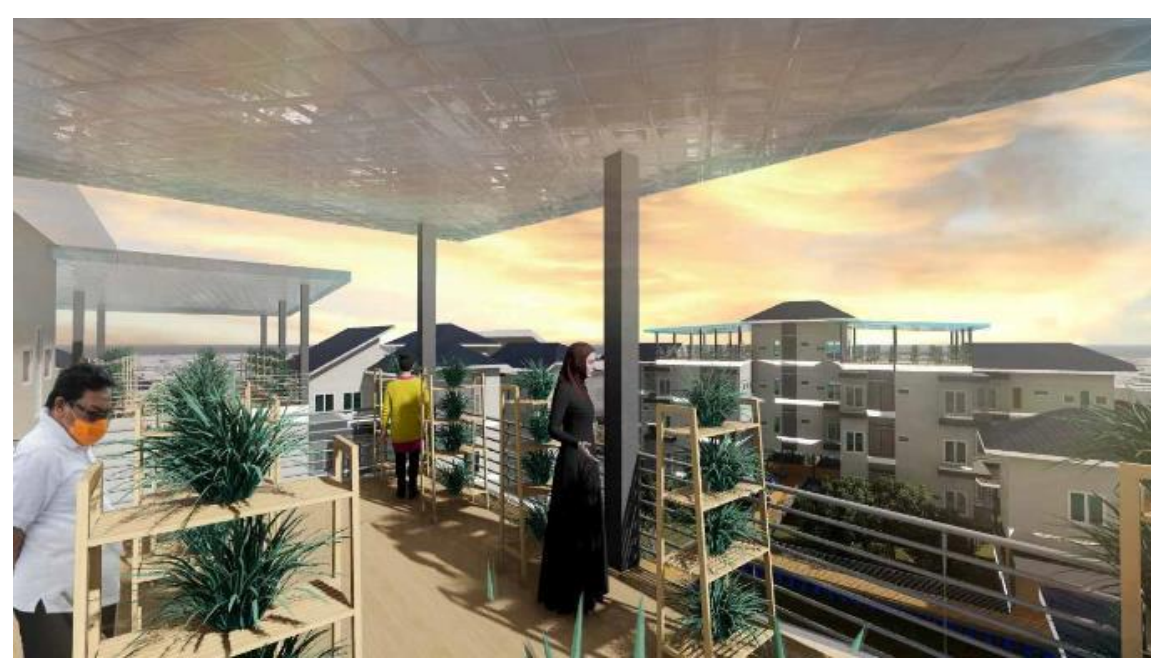

Gambar 21. Perspektif Kebun Organik

Sumber: Penulis, 2021

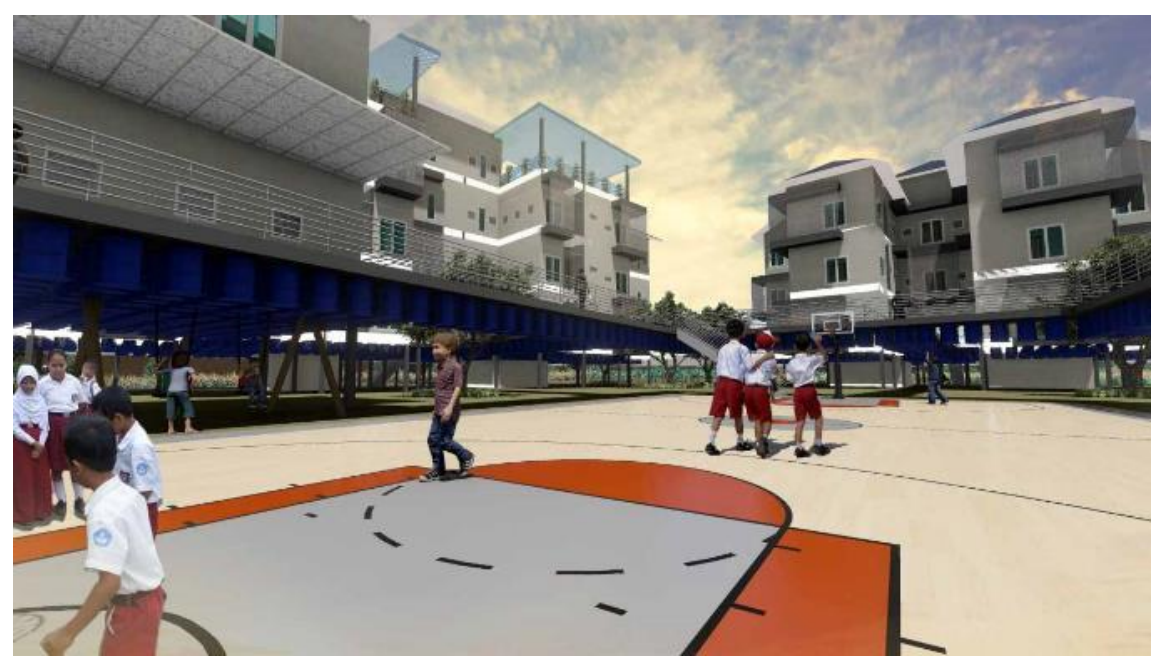

Gambar 22. Perspektif Lapangan

Sumber: Penulis, 2021 


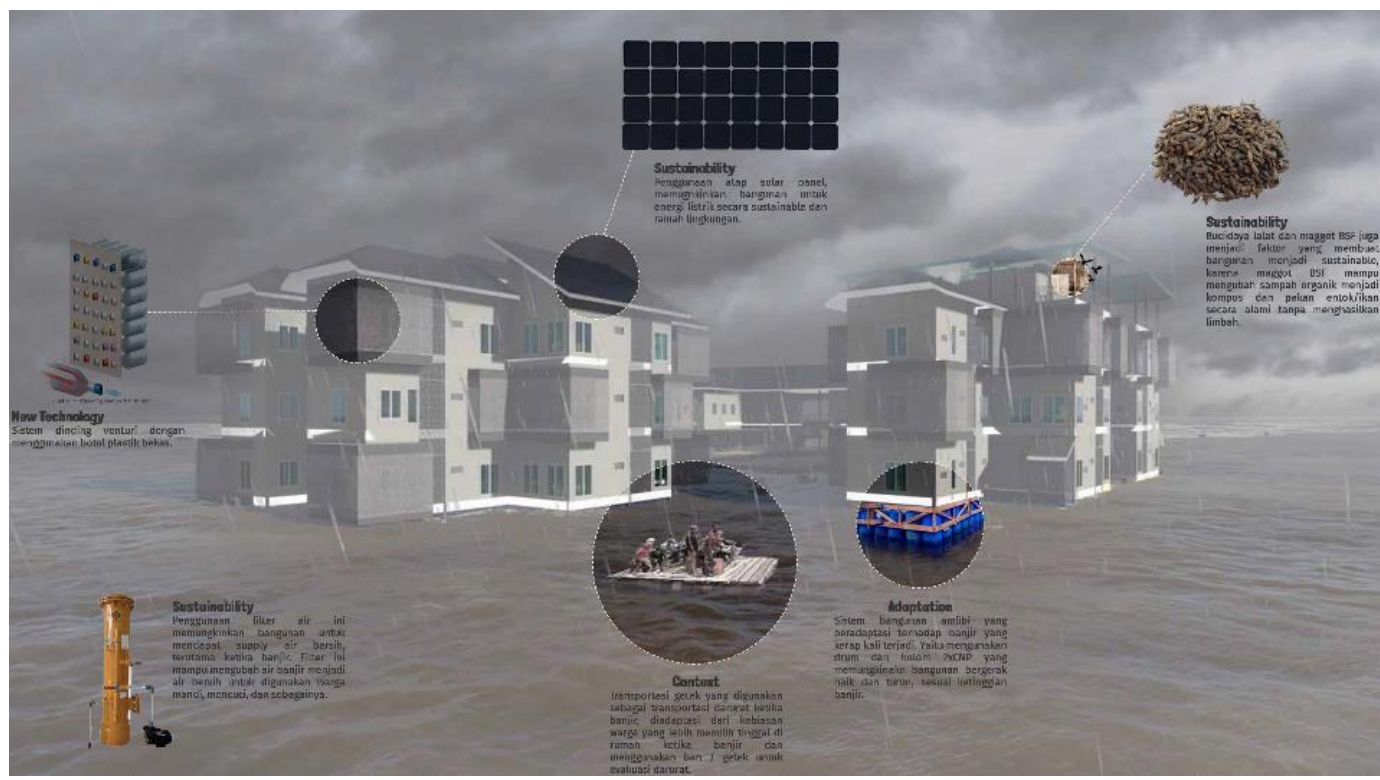

Gambar 23. Diagram Beyond Ecology

Sumber: Penulis, 2021

\section{KESIMPULAN DAN SARAN}

\section{Kesimpulan}

Masalah banjir yang terjadi di Jakarta tidak pernah ada habisnya. Oleh kerena itu, tata kota Jakarta harus menjadi ramah air. Dalam lingkungan yang rawan banjir, proyek ini mencoba berinovasi dengan sistem bangunan amfibi untuk tidak melawan banjir, tetapi hidup berdampingan bersama banjir. Proyek ini juga mencoba mewadahi berbagai kebutuhan warga baik ketika banjir maupun ketika tidak banjir, supaya bangunan dapat berfungsi secara optimal dan fleksibel. Proyek ini juga didesain sesuai dengan kebiasaan-kebiasaan warga setempat, sehingga mereka dapat nyaman tinggal di Kampung Pejaten Timur.

\section{Saran}

Dalam mendesain bangunan apung, perlu dipertimbangkan bahan dan material yang digunakan. Hal ini sangat berpengaruh terhadap ketahanan terhadap banjir serta penggunaan material yang ringan untuk memudahkan bangunan mengapung. Berbagai kebutuhan dan aktivitas warga juga perlu diperhatikan, supaya kebutuhan warga terutama ketika banjir dapat terpenuhi.

\section{REFERENSI}

Marden, G. (2021) "Common Construction Methodes and Log Float Specs". https://oregonfloating-

homes.com/floating_homes_for_sale_in_portland_oregon_log_floats.htm\#illustration_2_ _log_floats_common

Ngaenan. (2018). "Arsitek Yu Sing: Banjir Karena Jakarta Melawan Air". https://www.indopress.id/article/analisa/arsitek-yu-sing-banjir-karena-jakarta-melawanair

Pusat Penelitian Fisika. "Air Banjir Layak Minum". http://lipi.go.id/risetunggulan/single/alatpengolah-air-banjir-layak-minum/41

Rizky, F. (2021). "Banjir hingga 3 Meter, Warga Pejaten Timur Ngemper di Rumah Tetangga". https://megapolitan.okezone.com/read/2021/02/08/338/2358759/banjir-hingga-3meter-warga-pejaten-timur-ngemper-di-rumah-tetangga

Sasongko, T. J. (2021). "Cara Budidaya Maggot BSF Pemula Tanpa Bau, Dijamin Menguntungkan". https://gdm.id/budidaya-maggot/ 